\title{
Well-Being in the Nordic Countries: An International Comparison
}

\author{
Stefán Ólafsson, D. Phil., Professor of Sociology, University of Iceland
}

\begin{abstract}
This study asks how well the Nordic nations have managed in a new social environment of globalization, increasing competition and new challenges to the Nordic welfare model? The focus is on well-being outcomes, rather than on welfare inputs (expenditure generosity or rights and institutional features). For this purpose we have constructed a data bank with well-being measures for 29 modern nations, based on 69 variables in 9 well-being dimensions. With this data we have constructed an overall well-being index and sub-indexes for these nations. We find that in terms of well-being outcomes the Nordic nations (including Iceland) share major patterns of well-being characteristics. In a data-driven clustering analysis (with Dendograms, using the Ward Method) of all the 69 variables, our well-being outcomes cluster the nations in a way comparable to Francis Castles' families of nations and Esping-Andersen's main welfare regime types. We disaggregate the outcomes by clusters and well-being dimensions. The findings indicate that the five Nordic nations had the highest level of well-being amongst modern nations during the period from 2005 to 2008, along with Netherlands, Switzerland and Luxembourg. The strength of the Nordic cluster of nations seems to be their emphasis on equality of income distribution, poverty reduction, improving family conditions and facilitating social cohesion and participation, while also promoting economic strength and a high affluence level. The study also assesses correlates of well-being amongst these nations, including welfare state generosity, political influences, social trust, strength of democracy and distributional characteristics. The findings support a narrative emphasizing the importance of lifting the worse off up the well-being
\end{abstract}




\section{STJÓRNSÝSLA}

ladder of society. That seems to be the most efficient strategy for improving the overall well-being of modern nations.

Keywords: Well-being measures; Nordic model; Correlates of well-being.

\section{Introduction}

The Nordic countries have featured prominently in international comparisons of qualities of life or well-being during the last decades. Renowned as representatives of a special welfare state model (the Scandinavian welfare regime, family or cluster), these countries have indeed been recognized as a region of high living standards, successfully mixing competitive markets and a caring and equalizing welfare state.

This position of the Scandinavian nations was already in place by the 1970 s and further consolidated during the 1980s and 1990s (Castles 1978; Erikson et. al. 1987; Esping-Andersen 1990 and 1999; Castles 1993 and 1998; Kautto et. al. 2001).

Recent decades have seen wide-ranging social changes, such as increasing globalization in the external environment, with growing restraints on public welfare provisions. Internally problems of aging, economic changes and societal modernization have also heralded the emergence of new risks and problems. These changes warrant a question of how well the Nordics have managed in a new social environment? Have they maintained their position as societies with a distinctly high level of living for the great majority of its citizens? Or has the Nordic Model been eroded with increasing neoliberal globalization, leading to increased inequalities and reduced well-being of the common citizens?

We address these issues in this paper, with a special focus on welfare outcomes (wellbeing of publics), rather than on welfare inputs (welfare expenditure generosities, rights and institutional characteristics). For this purpose we have constructed a data bank with well-being measures for 29 modern nations. These measures (69 variables in all) are aggregate OECD and Gallup World Poll statistics, from standardized public sources and international surveys, along with a few others of a similar genre. The period that the data covers is primarily between 2005 and 2008, or pre-crisis data.

With this data we have constructed an overall well-being index for each of these 29 nations, following a similar approach as with the UN's Human Development Index. Instead of relying on three dimensions and four variables, as has been common with the HDI index, we are working with sixty-nine variables and nine sub-dimensions of well-being. The scores on these sixty-nine variables are normalized (with z-scores) and aggregated into dimension averages. These are then averaged into the total well-being score for each country and each cluster of countries. In the appendix we explain the data further, as well as on a public website providing extensive access to the underlying data and methods (see www.ts.hi.is/gagnagrunnur).

Hence we are able to do extensive comparisons of individual nations as well as clusters or regimes or families of nations, both on the overall well-being outcome as well as on the individual sub-indexes, such as for economic strength (affluence and economic competitiveness), health condition of the publics, employment level, educational attain- 
ment level, income equality, poverty reduction, family conditions, social cohesion and participation, and lastly subjective well-being. Hence we can probe behind the overall outcome and characterize the foundations of the good life in these nations, indicating where they do well and where they do not so well. Then we can also correlate these outcomes to antecedent characteristics, such as institutional characteristics and sociopolitical features of the nations in our sample.

We find that in terms of well-being outcomes the Nordic nations (including Iceland) share major patterns of well-being characteristics. In a data-driven clustering analysis (with dendograms using the Ward Method) of all the 69 variables for all the 29 countries, the well-being outcomes cluster the nations in a similar way as Francis Castles' families of nations and Esping-Andersen's main regime types (with later additions). That is also in accordance with Castles and Obinger's (2008) finding of a significant coherence between policy antecedents and policy outcomes in modern nations. We therefore use these main clusters in our comparison as well as scores for individual nations.

The Nordic cluster compares well in direct well-being achievements in the period of 2005-2008, generally ranking the highest of these 29 nations, along with Netherlands, Switzerland, Luxembourg and Austria. The English-speaking nations rank lower, along with Belgium, France and Germany. An Eastern-European cluster of post-communist nations (Poland, Portugal, Hungary and Slovakia) ranks the lowest in our sample, below a Southern-European cluster (Italy, Spain, Greece and Portugal) and an Asian cluster (represented only by Japan and South Korea).

We also find that an important feature of the good outcome for the Nordic cluster and the higher-ranking Continental nations is a shared strong emphasis on distributional measures (through public welfare states and taxation systems) and effective poverty reduction measures. Hence the real earnings of the lowest income group (lowest income decile) have in general the strongest correlation to our overall well-being index, suggesting that the strategy of lifting the bottom of the level-of-living ladder is the most effective strategy of increasing the overall well-being of publics. That eradicates the many correlates of poverty as well as building a stronger foundation for health, education, employment, social capital and democracy.

\section{Approach and data}

\subsection{The approach}

The study is based on a multi-dimensional approach to measuring well-being, in line with the thinking on which the Scandinavian level of living surveys were based (Johansson 1973 and 2002; Allardt and Uusitalo 1972; Allardt 1975) and in line with some recent work carried out by the OECD (2009a, 2009b, 2011a, 2011b; Boarini et. al. 2006) and on behalf of the European Union in recent years (Atkinson et. al. 2002; Marlier et.al. 2007; Atkinson and Marlier 2010). See also Smeeding (2012), Nolan and Whelan (2011), Stiglitz, Sen and Fitoussi (2009) and Bradshaw and colleagues (2006). We have also been influenced by Osberg's and Sharp's (2009 and 2011) work on the Economic Well-being Index in Canada, as well as the methodology of UN's Human Development Index 


\section{STJÓRNSÝSLA}

(http://hdr.undp.org/en/statistics/hdi/). Former work of our own has also contributed to the development of the approach used in this research (for example Ólafsson, 1990, 1999, 2010, 2012).

A multi-dimensional approach involves a wide understanding of quality of life or well-being, going significantly beyond the narrow economic GDP measure of national affluence. Besides being a narrow focus on quality of life the GDP per capita measure on its own overlooks the distributional effects on the well-being of nations. If a large GDP per capita is very skewed in distribution, such that the top $10 \%$ or even the top $1 \%$ takes a large share of the national income at the cost of the lower part of the population, then that significantly affects the outcome for the majority. The GDP measure in such a case gives a very misleading indication of the well-being of the median or the lower half of the nation. This is in many ways the situation in the USA, which has had one of the highest average affluence levels (measured by GDP per capita) for decades. A very unequal distribution of that affluence means that alongside with very extravagant affluence there is dire widespread poverty and in some ways those near the middle do not compare particularly well with median families in some other Western countries.

Hence distribution matters. Other aspects matter too. The multi-dimensional approach seeks to fill in the gaps left by the sole measure of GDP/pc by incorporating measures of the most important aspects of well-being that matter to the general public in modern societies, as well as take account of distributional effects and poverty reduction.

Some observers might object to income equality being taken as an indication of more well-being of nations, for example those adhering to neoliberal ideology. A modest level of equality however means that the great majority of the nation enjoys the average affluence level to a greater extent than would be the case in a much more unequal society. Hence a higher degree of equality can be taken as an indication of a better relative position for the great majority. A high level of well-being for the top $1 \%$ of the income and wealth ladders may not mean a particularly high level of well-being for the median population and can coexist with quite extensive and deep poverty, as in the USA. A more balanced sharing of the national income means in general a higher level of well-being for the majority, given the average affluence level of the nation in question (Wilkinson and Pickett 2010).

The nine sub-dimensions of the well-being index that we have constructed are the following:

- Economic strength and competitiveness (average of 5 variables)

- Health condition (11 variables)

- Employment level (9 variables)

- Educational level (6 variables)

- Income equality (3 variables)

- Poverty reduction (7 variables)

- Family conditions (9 variables) 
- Social cohesion and participation (7 variables)

- Subjective well-being (12 variables)

- Total Well-Being Index (average of the 9 sub-indexes)

The $z$-scores for the variables in each dimension are averaged to constitute a sub-index and these are then averaged to create the total WB Index.

All composite indicators are vulnerable to criticisms of design and coverage. Indicators based on only a few dimensions and few measures are particularly susceptible to claims that the specific composition determines the outcomes. The strength of our index is the large number of dimensions and the large number of variables. The choices are in most cases sensitive to what we consider self-evident references to what can be taken as indicators of good qualities of life for the big majorities of nationals in the respective countries. Those choices can of course be questioned, for example from widely differing cultural perspectives. Including only a sample of more modern nations in our index reduces the strength of such criticisms.

While more variables are a strength we cannot however claim to have anything like a "complete" or the "one correct measure" of the "good life". No one has and in fact no such achievement is necessary for the undertaking to be useful as a contribution to knowledge, given that reliability and validity are reasonably fulfilled.

\subsection{Reliability and validity}

Most of the variables we use are well known and well tested as measures and the sources are also well known and respected. That provides reliability. Most of the variables come from OECD reports or OECD data banks, many are from Gallup International's World Poll and a few come from World Economic Forum. In assessing the reliability and validity of the index we have further used data from International World Values Survey and the European Social Survey, Legatum Prosperity Index, Jonathan Bradshaw's international index of child well-being and indices of extreme poverty in Europe, Ruut Veenhoven's indices of happiness and happy life years, to mention only a few. In assessing the validity of the index we have also used data from various academic researchers and from Eurofoundation's Quality of Life Survey amongst the EU member countries, undertaken in 2007.

In figure 1 we show one indication of validity of our index by correlating it to a measure from Eurofoundation's 2007 Quality of Life Survey for EU member states (Eurofound 2009 and 2010). The measure is respondents' aggregated answers to the statement "On the whole, my life is close to how I would like it to be" (\% who say they "strongly agree" or "agree").

As seen from figure 1 the correlation is very high $\left(\mathrm{R}^{2}=0.81 ; \mathrm{r}=.9\right)$. The data here only covers the European Union member countries whereas our index also covers North America (USA and Canada) and some Asian nations as well (Australia, New Zealand, Japan and South Korea). Our index has a .79 correlation to the Human Development Index for 2005, it has a .89 correlation to the recent OECD ranking of its Headline 


\section{STJÓRNSÝSLA}

Social Indicators and the correlation of WBI to Jonathan Bradshaw's index of Child Well-Being is .85.

Figure 1. Relationship between the WBI and Eurofound's 2007 Quality of Life Survey results to the question "On the whole, my life is close to how I would like it to be" (\% agree)

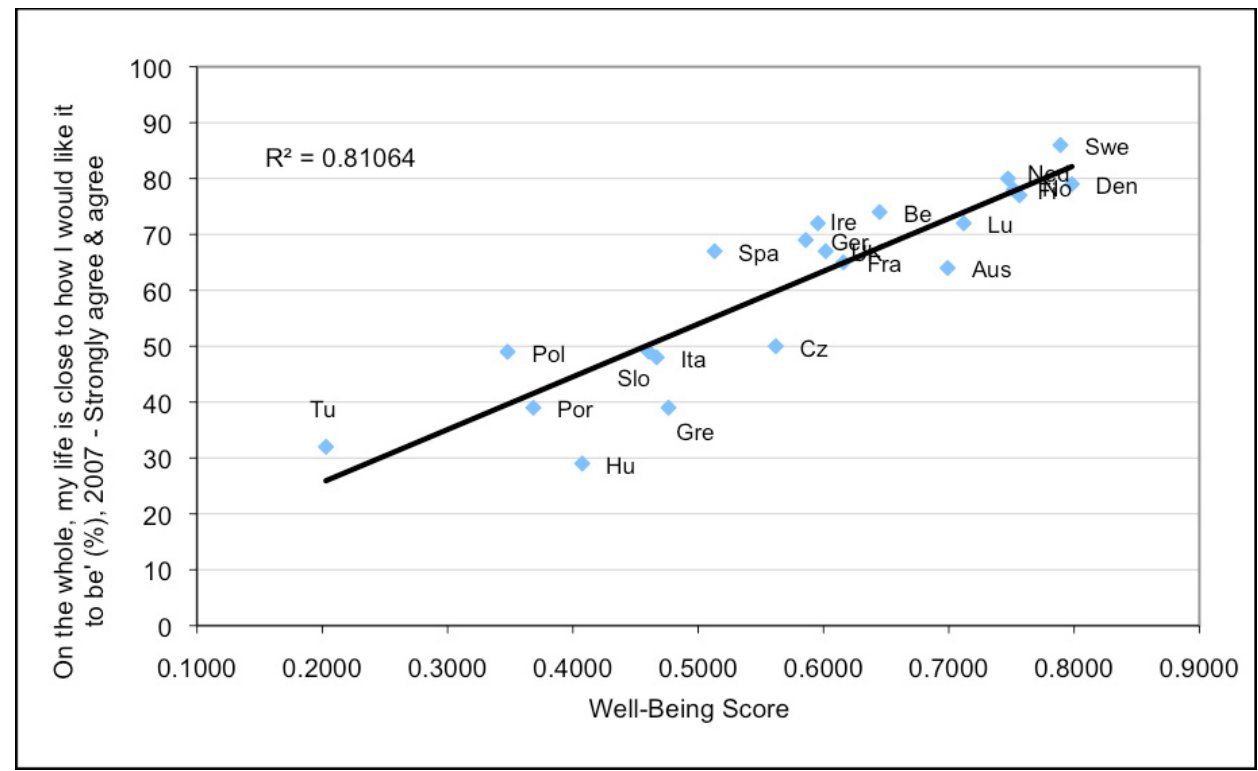

On the whole we can state that our index has a strong correlation (0.7-0.9) to other well known measures of well-being or quality of life, but still it adds its own contribution, which emanates from its specific composition (see correlation tables on the WBI web site - www.ts.hi.is/gagnagrunnur).

\section{Well-being of Nations: Overall Outcomes and Clustering}

In figure 2 we show the overall well-being scores for each country and cluster means. The outcome ranks the Nordic nations and Netherlands the highest, closely followed by Switzerland, Luxembourg and Austria. This is in line with many outcomes in various recent comparative studies of welfare or well-being. The Nordics generally do well in comparisons and benchmarking of various social and economic aspects of level of living (see for example OECD 2009a, 2009b, 2011a and 2011b; UNICEF 2013; Helliwell, Layard and Sachs 2012: Gallup World Poll 2010; Gallup-Healthways 2009; Osberg and Sharpe 2009).

This favourable outcome for the Nordic nations is also in line with the findings of Castles and Obinger (2008) about commonalities of public policy patterns. The Nordic countries indeed share many similarities in their patterns of public policies, as well as in structural features of their societies, such as a strong and influential labour union movement, significant long-term influences of social democratic politics and egalitarian and 
Well-Being in the Nordic Countries:

STJÓRNMÁL

An International Comparison

Stefán Ólafsson

participative cultures. This outcome also seems to be associated to a rather high degree of social mobility in the Nordic countries (Corak 2013; OECD 2008), a high degree of income equality (OECD 2008 and 2011c; Atkinson and Piketty 2010) and a low vulnerability of the worse off to social exclusion and poverty (Whelan and Maitre 2009 and 2012; Bertelsmann Stiftung 2011).

The outcome of Netherlands, Switzerland and Luxembourg is also very favourable. It is of course not new that Netherlands ranks on level with the Scandinavian nations in comparisons of well-being and levels of living, since there are many commonalities in the welfare systems of these countries. Switzerland and Luxembourg combine a very high level of affluence with significant welfare provisions and redistribution measures.

Figure 2. Overall Well-Being score for 29 modern countries and cluster averages

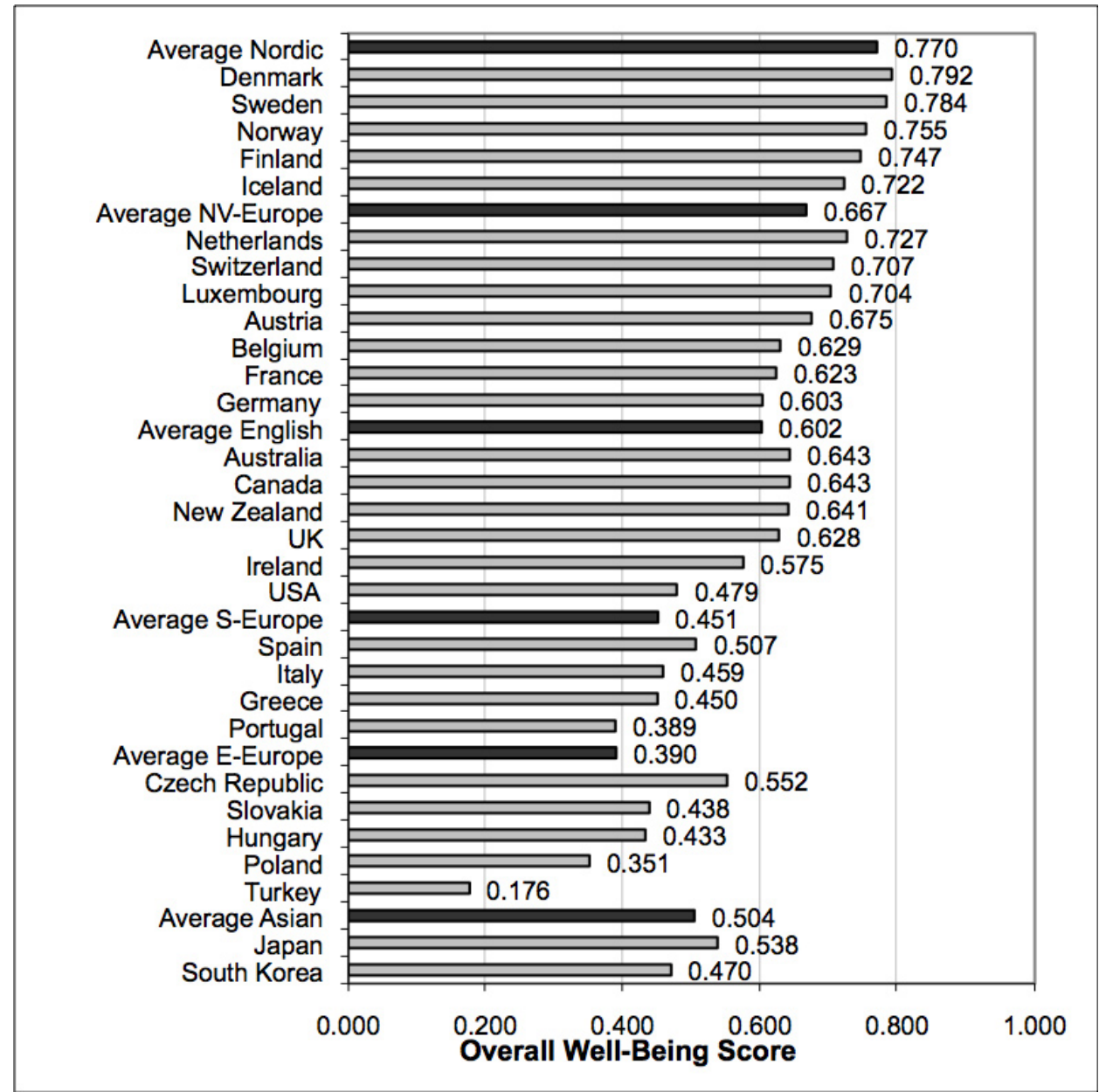

Note: The clusters are based on a Dendogram analysis of all 69 variables, using the Ward Method. See appendix for description of data and variable list. 


\section{STJÓRNSÝSLA}

The higher-ranking English-speaking nations (Australia, Canada, New Zealand and the $\mathrm{UK}$ ) do somewhat better than the lower ranking of the NW-European nations (Belgium, France and Germany), but the USA is significantly lower in its well-being outcome. In fact in the cluster analysis the USA borders on being included in the cluster of the English-speaking nations or with the Asian nations of Japan and South Korea. That is mainly due to the high level of inequality and relative poverty in the otherwise very affluent USA.

The Southern European nations (Spain, Italy, Greece and Portugal) rank significantly lower than the NW-European nations. While the Eastern European nations on average rank lower than the S-European ones, the Czech Republic is higher and Slovakia and Hungary do similarly. This appears to be primarily due to redistributive policies, benefiting the lower level groups. Poland and Turkey have the lowest scores of well-being in this group.

The two Asian nation included (Japan and South Korea) rank higher than the Southern and Eastern nations, except Spain and the Czech Republic.

In the next section we probe further into reasons for varying outcomes for the nations.

\section{Well-being of Nations Disaggregated 3.1 Country profiles}

In table 1 we show the ranking of the 29 nations by sub-dimensions, along with the mean rank and the coefficient of variation. This gives an indication of what is behind the varying outcomes for individual nations. Thus we can see where the strong and the weak points are in each case. While some nations and groups of nations rank high on many measures and others rank low on many measures it is also quite common for nations to rank high on some aspects, medium on others and low on some as well. Hence the overall outcome is usually a composite of varying compositions.

On the whole the higher ranking nations have more consistency in their scores across the sub-dimensions, as revealed by the coefficient of variation. The difference in variation between the Nordic, NW-European and some of the Anglo-Saxon nations are small. The USA has though a significantly higher variation across dimensions than the other English speaking nations. The lowest ranking nations on the other hand have greater variation between dimensions. Even though Turkey consistently ranks from the 26 th to 29 th its $z$-scores vary a lot, from zero to 0.42 .

Looking at individual nations we can identify significant variations in outcome patterns. Hence at the top Denmark has the top rank for three dimensions while it is just below average rank for economic strength, health conditions and educational level. Hence Denmark does not get the top scores on all dimensions. Sweden and Norway have a stronger profile as high ranking on all dimensions, while Finland is quite low on health in the Nordic cluster and Iceland is outstandingly so on educational level, due to a high rate of drop-out from secondary schools (OECD 2012). Netherlands has a persistently high rank across nearly all dimensions. 
Well-Being in the Nordic Countries:

STJÓRNMÁL

Table 1: Ranking of countries by sub-dimensions and overall well-being scores.

\begin{tabular}{|c|c|c|c|c|c|c|c|c|c|c|c|c|}
\hline & \multirow[b]{2}{*}{$\begin{array}{r}\text { Total Well- } \\
\text { being }\end{array}$} & \multirow[b]{2}{*}{$\begin{array}{c}\text { Economic } \\
\text { strength }\end{array}$} & \multirow[b]{2}{*}{$\begin{array}{r}\text { Health } \\
\text { conditions }\end{array}$} & \multirow[b]{2}{*}{$\begin{array}{r}\text { Employment } \\
\text { level }\end{array}$} & \multirow[b]{2}{*}{$\begin{array}{r}\text { Educational } \\
\text { level }\end{array}$} & \multirow[b]{2}{*}{$\begin{array}{l}\text { Income } \\
\text { equality }\end{array}$} & \multirow[b]{2}{*}{$\begin{array}{r}\text { Poverty } \\
\text { reduction }\end{array}$} & \multicolumn{3}{|c|}{ Social } & \multirow[b]{2}{*}{$\begin{array}{r}\text { Average } \\
\text { rank }\end{array}$} & \multirow[b]{2}{*}{$\begin{array}{l}\text { Coefficient } \\
\text { of variation }\end{array}$} \\
\hline & & & & & & & & $\begin{array}{r}\text { Family } \\
\text { conditions }\end{array}$ & $\begin{array}{l}\text { cohesion and } \\
\text { participation }\end{array}$ & $\begin{array}{l}\text { Subjective } \\
\text { well-being }\end{array}$ & & \\
\hline Denmark & 1 & 12 & 12 & 2 & 11 & 2 & 1 & 1 & 1 & 4 & 5.1 & 0.20 \\
\hline Sweden & 2 & 7 & 1 & 6 & 8 & 1 & 2 & 2 & 3 & 5 & 3.9 & 0.17 \\
\hline Norway & 3 & 4 & 2 & 5 & 12 & 3 & 3 & 4 & 9 & 3 & 5.0 & 0.15 \\
\hline Finland & 4 & 10 & 16 & 9 & 3 & 8 & 4 & 5 & 2 & 1 & 6.4 & 0.17 \\
\hline Netherlands & 5 & 9 & 4 & 4 & 9 & 10 & 11 & 8 & 5 & 2 & 6.9 & 0.16 \\
\hline Iceland & 6 & 8 & 6 & 1 & 21 & 5 & 8 & 3 & 6 & 10 & 7.6 & 0.19 \\
\hline Switzerland & 7 & 3 & 8 & 3 & 6 & 11 & 14 & 16 & 8 & 8 & 8.6 & 0.17 \\
\hline Luxembourg & 8 & 1 & 10 & 17 & 22 & 6 & 13 & 7 & 4 & 16 & 10.7 & 0.20 \\
\hline Austria & 9 & 14 & 13 & 10 & 20 & 7 & 5 & 14 & 7 & 11 & 11.2 & 0.20 \\
\hline Australia & 10 & 11 & 7 & 15 & 10 & 16 & 19 & 10 & 10 & 7 & 11.7 & 0.19 \\
\hline Canada & 11 & 6 & 11 & 12 & 1 & 18 & 20 & 21 & 13 & 6 & 12.0 & 0.16 \\
\hline New Zealand & 12 & 20 & 18 & 7 & 5 & 19 & 16 & 12 & 11 & 9 & 13.0 & 0.16 \\
\hline Belgium & 13 & 17 & 20 & 22 & 13 & 14 & 10 & 13 & 14 & 12 & 15.0 & 0.22 \\
\hline UK & 14 & 13 & 9 & 16 & 17 & 17 & 9 & 9 & 15 & 15 & 13.3 & 0.25 \\
\hline France & 15 & 19 & 17 & 20 & 14 & 13 & 6 & 6 & 16 & 19 & 14.4 & 0.17 \\
\hline Germany & 16 & 16 & 5 & 21 & 16 & 15 & 18 & 11 & 12 & 18 & 14.7 & 0.21 \\
\hline Ireland & 17 & 5 & 15 & 13 & 15 & 22 & 24 & 15 & 17 & 13 & 15.4 & 0.21 \\
\hline Czech Republic & 18 & 22 & 21 & 23 & 19 & 4 & 7 & 20 & 24 & 21 & 17.9 & 0.28 \\
\hline Japan & 19 & 18 & 14 & 8 & 2 & 24 & 26 & 19 & 18 & 25 & 17.1 & 0.34 \\
\hline Spain & 20 & 21 & 19 & 18 & 25 & 23 & 23 & 17 & 22 & 17 & 20.6 & 0.22 \\
\hline USA & 21 & 2 & 28 & 11 & 7 & 28 & 28 & 27 & 19 & 14 & 18.2 & 0.44 \\
\hline South Korea & 22 & 15 & 24 & 19 & 4 & 25 & 25 & 23 & 25 & 24 & 20.4 & 0.32 \\
\hline Italy & 23 & 24 & 3 & 24 & 27 & 21 & 21 & 26 & 23 & 20 & 21.0 & 0.36 \\
\hline Greece & 24 & 23 & 22 & 25 & 26 & 20 & 17 & 28 & 20 & 22 & 22.6 & 0.36 \\
\hline Slovakia & 25 & 25 & 25 & 27 & 24 & 9 & 15 & 25 & 28 & 27 & 22.8 & 0.44 \\
\hline Hungary & 26 & 26 & 29 & 26 & 23 & 12 & 12 & 18 & 27 & 28 & 22.3 & 0.60 \\
\hline Portugal & 27 & 29 & 23 & 14 & 28 & 27 & 22 & 22 & 21 & 26 & 23.6 & 0.50 \\
\hline Poland & 28 & 28 & 27 & 29 & 18 & 26 & 27 & 24 & 26 & 23 & 25.3 & 0.44 \\
\hline Turkey & 29 & 27 & 26 & 28 & 29 & 29 & 29 & 29 & 29 & 29 & 28.3 & 0.73 \\
\hline
\end{tabular}

See further on www.ts.hi.is/gagnagrunnur, for description of data and further comparisons.

Switzerland, which has a very high overall score, particularly on educational strength and employment level, is lower than the Nordics on poverty reduction and family conditions. Luxembourg has more variation between dimensions, topping every other nation in our sample for economic strength but not scoring so impressively on educational level, employment and subjective well-being.

Amongst the countries in the broad middle of the rank order of well-being (mainly populated by the NW-European and English speaking nations) a few interesting deviations can be observed. Thus Canada has the top rank for educational level while it is rather low for family conditions, poverty reduction and income equality. New Zealand is relatively high on education and employment levels but low on economic strength, health and the distributional dimensions, like income equality and poverty reduction.

France has a high rank for poverty reduction and family conditions but it is rather low on economic strength, employment as well as subjective well-being. The UK ranks relatively high on poverty reduction and family conditions, due to its relatively generous welfare benefits aimed at lower income groups, but it is still below average for education and income equality. Germany has a very high rank for health conditions, but it is below average for employment level, poverty reduction and subjective well-being.

Ireland, one of the economic sputnicks of the 1990s and 2000s, has a very high rank on economic strength, but it is low on poverty reduction and income equality. Japan has an outstandingly high rank for education and employment but it is very low on poverty reduction and income equality, as well as on subjective well-being.

The USA has the second highest rank for economic strength, after Luxembourg, but is near the bottom on health conditions, poverty reduction, income equality and family conditions. 
Amongst the remaining nations what stands out in terms of deviations or particular characteristics is Italy's very high rank on health conditions, the Czech Republics high rank on income equality and poverty reduction, South Korea's high educational rank, and Slovakia's relatively high rank on income equality. Lastly Portugal which generally ranks low on the well-being dimensions has a near average rank for employment level, due to high employment participation rates.

\subsection{Cluster profiles}

As we indicated in the first section our cluster analysis of the sixty nine well-being measures fairly consistently produced six clusters of nations, similar to Francis Castles' and Herbert Obinger's five families of nations clusters in Europe, in addition to an Asian cluster (only represented by Japan and South Korea). Next we analyse the patterns and characteristics of these six cluster groups in terms of the nine sub-dimensions (see figure 3). The clusters share a significant degree of commonality in the well-being outcomes across dimensions, despite the occasional deviations, as we have shown in table 1.

Looking first at the Nordic cluster the outstanding shared strength of that group of nations is particularly great emphasis on poverty reduction, income equality, social cohesion and participation, along with favourable family conditions. The Nordics also have on average the highest rating of subjective well-being, reflecting a high degree of citizens' satisfaction with their own life and the main features of their social environment (see variable list in the Appendix). At the same time the Nordic nations rank relatively high on employment level (reflecting very high employment participation rates with modest working-hours) and economic strength. The weakest dimensions for the Nordic nations are education (except for Finland, which has the third highest rank there) and health. Still the Nordic nations' scores for health are quite respectable compared to the other clusters.

The North Western European nations are closest to the Nordic well-being pattern, with strength on the equality, poverty reduction and family conditions dimensions and a comparatively high rating on subjective well-being. These nations score similarly strongly on economic strength and health but significantly lower on employment, reflecting the more conservative regime characteristics mapped in Esping-Andersen's studies (1990 and 1999). These nations also score even lower than the Nordics on educational level. As we showed above there is some difference between the more prosperous continental countries (Netherlands, Switzerland and Luxembourg) and the others of that cluster (Austria, Belgium, France, Germany), with the latter scoring lower than the former, yet with a similar pattern across the dimensions. 
Well-Being in the Nordic Countries:

STJÓRNMÁL

An International Comparison

Stefán Ólafsson

STJÓRNSÝSLA

Figure 3. Cluster Profiles: Six clusters of nations. Total WB index and 9 sub-indexes for each. Deviations from means of sub-indexes. The zero-line is the mean in each case

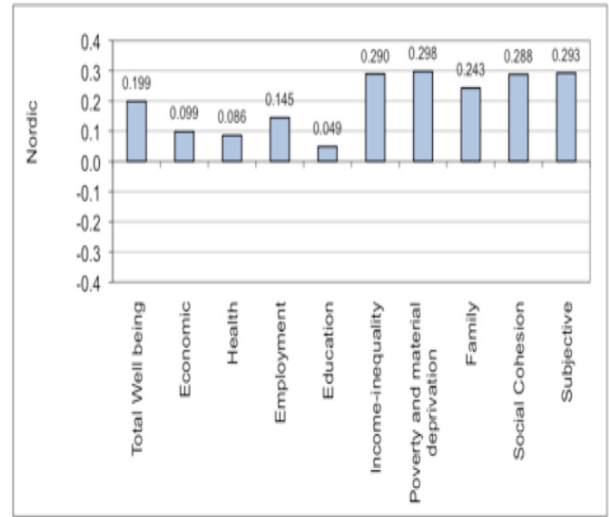

Nordics

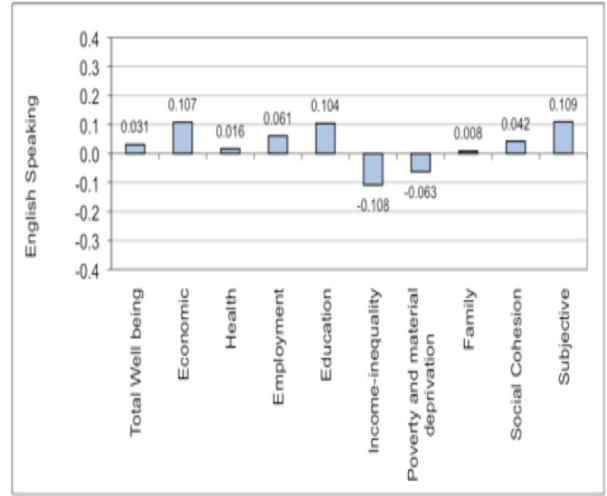

English Speaking

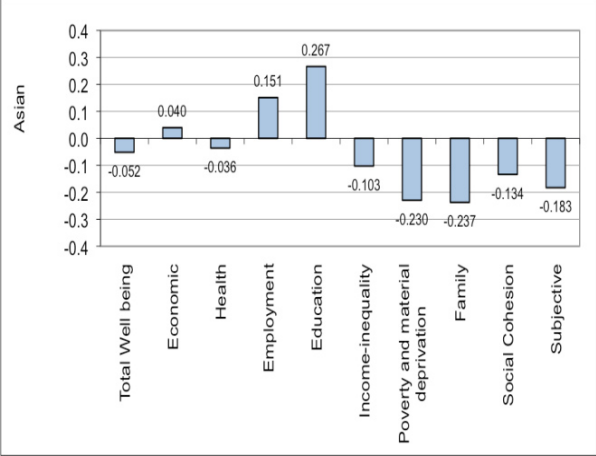

Asian

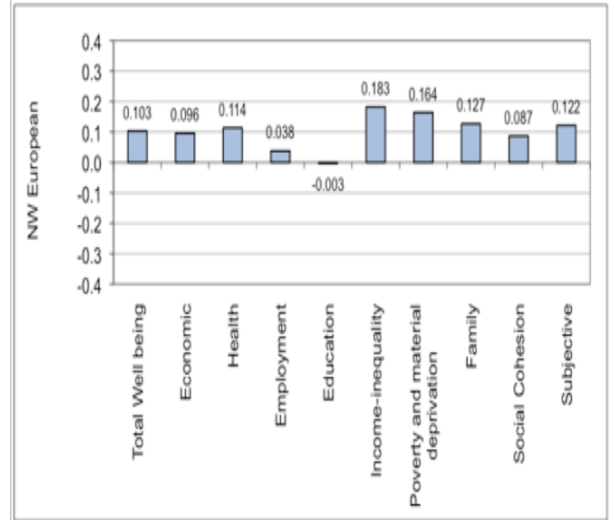

North Western European

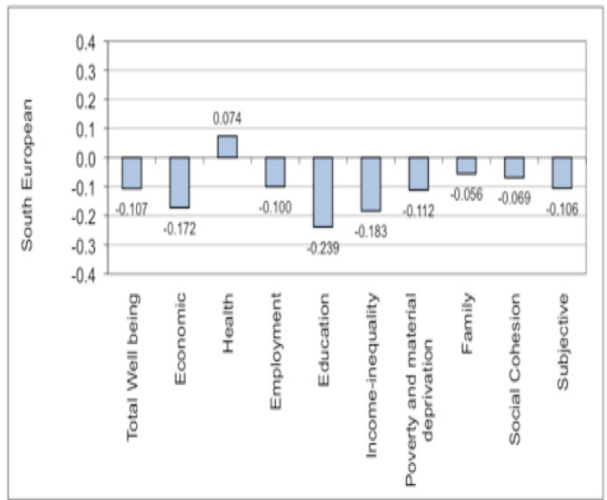

Southern European

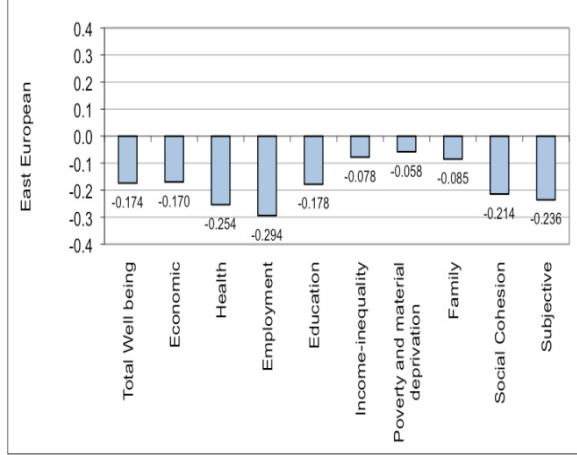

Eastern European 


\section{STJÓRNSÝSLA}

The English speaking nations as a whole have a specific pattern, fundamentally different from that of the previous two clusters. This is exemplified by a great economic strength and a high educational level, but a decisively low emphasis on income equality, poverty reduction and family conditions. This low showing on the distributional dimensions is what primarily distinguishes the English speaking nations from the Nordics. The English speaking are also significantly lower on social cohesion and participation, as well as on subjective well-being.

The USA is a bit of an extreme example of this cluster pattern, scoring decisively lower than other members of its cluster on the poverty reduction and income equality dimensions, as well as on social cohesion and participation. In addition the USA has a very low score on health condition. It deviates further from the Nordic pattern than other members of the English speaking cluster.

The Southern European cluster scores below the means for all dimensions, except on health condition. They score lowest on educational level, income equality and economic strength, but less so on family conditions and social cohesion. The Eastern European cluster similarly scores below the mean on all dimensions, lower than the Southern cluster on employment, health and social cohesion, but not so on income equality and poverty reduction. The last point reflects the special situation of countries like the Czech Republic, Slovakia and partly Hungary, with their redistributive characteristics.

The Asian cluster lastly has its main strengths in education and employment, but it scores weakly on the distributional dimensions and the subjective well-being dimensions, on which the Nordics score the highest. These two Asian nations thus share these characteristics to a significant degree with the USA.

The patterns we observe across clusters of nations exemplify a significant degree of commonality of well-being outcomes by the groupings we have worked with. Given that these groupings are common with the main genre of studies characterising regime and family patterns of social structural features of these groups of nations and their patterns of public policies we can expect that there are societal and political explanations for these regularities in the outcomes (Esping-Andersen 1990 and 1999; Castles 1993 and 1998; Castles and Obinger 2008). This is an important outcome given the extensive changes in the external and internal societal environment of the last decades.

\section{Relations between dimensions of the WB index}

In general the sub-indices correlate strongly to the total index (from .64 to .92), with education having the lowest coefficient. Social cohesion, family conditions and subjective factors have the strongest association to the overall outcome (.89-.92). Employment level, income equality and poverty reduction are lower but at similar levels (.78-.81). There is on the whole considerable consistency between the dimensions, with significant variations though.

Economic strength, based on measures of real affluence, competitiveness and economic growth, has a correlation of .75 to the WBI. That sub-index has the lowest association to the distributive variables of income equality and poverty reduction, but 
also relatively low association to health condition, family condition and education. This points to the significant divergence between the affluence level and distributive outcomes for the lower and middle earnings groups in some of the societies, that we have referred to. Still the economic dimension has a .68 correlation to the eight non-economic dimensions taken together. There are however deviations as we show below.

Educational level introduces the greatest diversity into the index, with low correlations to health condition, poverty reduction and income equality (.27-.38). The indication may be that education contributes to overall well-being more in the long-run than in the short-run.

Table 2. Correlation matrix for the index dimensions

\begin{tabular}{|c|c|c|c|c|c|c|c|c|c|c|c|}
\hline & $\begin{array}{c}\text { Total Well } \\
\text { Being }\end{array}$ & $\begin{array}{l}\text { Economic } \\
\text { strength }\end{array}$ & \begin{tabular}{|c} 
Total Non- \\
Economic \\
factors
\end{tabular} & $\begin{array}{c}\text { Health } \\
\text { condition }\end{array}$ & $\begin{array}{c}\text { Employment } \\
\text { level }\end{array}$ & $\begin{array}{c}\text { Educational } \\
\text { level }\end{array}$ & $\begin{array}{l}\text { Income } \\
\text { equality }\end{array}$ & $\begin{array}{c}\text { Poverty } \\
\text { reduction }\end{array}$ & $\begin{array}{c}\text { Farnily } \\
\text { conditions }\end{array}$ & $\begin{array}{c}\text { Social } \\
\text { Cohesion }\end{array}$ & $\begin{array}{c}\text { Subjective } \\
\text { factors }\end{array}$ \\
\hline Total Well Being & 1,00 & & & & & & & & & & \\
\hline Total Non-Economic & 1,00 & 0,68 & 1,00 & & & & & & & & \\
\hline Health condition & 0,71 & 0,52 & 0,70 & 1,00 & & & & & & & \\
\hline Income equality & 0,79 & 0,39 & 0,81 & 0,43 & 0,40 & 0,38 & 1,00 & & & & \\
\hline Poverty reduction & 0,78 & 0,33 & 0,81 & 0,43 & 0,42 & 0,27 & 0,93 & 1,00 & & & \\
\hline Farnily conditions & 0,91 & 0,56 & 0,92 & 0,59 & 0,72 & 0,54 & 0,77 & 0,77 & 1,00 & & \\
\hline Social Cohesion & 0,92 & 0,73 & 0,91 & 0,74 & 0,83 & 0,47 & 0,59 & 0,64 & 0,81 & 1,00 & \\
\hline Subjective factors & 0,89 & 0,72 & 0,87 & 0,69 & 0,79 & 0,58 & 0,51 & 0,54 & 0,74 & 0,89 & 1,00 \\
\hline
\end{tabular}

Health condition has the greatest association to social cohesion, subjective factors and to employment level. Employment level, much like the economic dimension, has its lowest correlation to income equality and poverty reduction and the strongest relationship to social cohesion and subjective factors. Income equality and poverty reduction are very strongly interrelated (.93) and both are also closely related to family conditions (.77).

Family conditions have the lowest association to education, economic strength and health. Social cohesion is most closely related to subjective factors, employment level, family conditions and then to economic strength.

Along with family conditions and social cohesion the subjective factors have most consistently higher correlations to most of the other sub-indices. The weakest associations to the subjective factors are from income equality, poverty reduction and educational level.

\section{Some correlates of well-being}

Since our 29 nations cluster, on the basis of extensive measures of well-being outcomes, on the lines of groupings (regimes, families of nations) that have emerged with socio structural and policy pattern variables, we could hypothesize that explanations for our outcomes could be sought in the determinants of the regime and family types of clusters, exemplified by the schools originated by Gösta Esping-Andersen and Francis Castles (see Obinger and Wagschal 2001 and Art and Gelissen 2002). Hence institutional landscapes and path dependency, political power distributions, strength of unions, wel- 


\section{STJÓRNSÝSLA}

fare state characteristics and generosity, redistributive taxation systems, specific poverty reduction measures and general affluence levels are likely to have been parts of the shaping of the varying outcomes we find. The role of explanatory variables has though most likely been different between countries, clusters and time periods.

Thus long-term influence of social democratic politics has played a large role in four of the five Nordic countries (Iceland has not been social democratic to the same extent), while strong unions have had a large role in all of them (Korpi 1983; Esping-Andersen 1985; Esping-Andersen and Korpi 1987). Culture and economic structures (small open economies dependent on fluctuating external conditions) have also been important in the Nordic countries (cf. Arnason and Wittrock 2012; Katzenstein 1985).

In the Continental nations Christian democracy and corporatist policy-making has played a large role in shaping distributional outcomes of levels of living or well-being (Kersbergen and Manow 2009) and in the Southern countries a large role for familism in conjunction with a smaller public welfare state has been more important than in the North (Ferrera 2010). In the Eastern European nations the socialist heritage and its collapse had a special influence, varying somewhat though between nations. The English speaking nations have for long had a strong liberal heritage and in the USA the absence of socialist influence (weak unions, weak or no social democracy) played an important role in restraining public provision of welfare and redistribution (Lipset 1963; Castles et.al. 2010). Then the Asian countries that we included have their own special societal environment and unique historical experiences that shaped their levels of living, along with political influences and compromises.

Given the limited space we will not venture into an extensive analysis of causes of the varying outcomes we find. The clustering of well-being outcomes connects well with previous findings of families of nations in terms of public policy patterns and shared regional and cultural forces, or alternatively with the regime tradition emphasizing political power distributions and structural features of the societies. In that sense these prevailing traditions provide general accounts for our broad outcomes. We indeed find strong correlations between our well-being index and variables representing the family of nations and welfare regimes explanatory variables.

In this last section we will thus not repeat aggregate statistical analyses to find the "few correct" explanatory variables. Instead we will show some interesting associations, by means of scaterplots, and try to build them into a narrative that draws attention to explanatory factors that have not figured particularly prominently in accounts of varying welfare regimes or families of nations. This concerns social trust, strength of democracy and the real earningspower of low income groups. We start by examining the association between our overall well-being index and welfare state generosity, before moving on to these other variables.

\subsection{Well-being and welfare states}

The welfare state being a redistributive mechanism, along with the taxation system, can be said to aim for transferring from those of better means to those of lesser means. 
That should facilitate a higher average well-being level for the society as a whole, according to utilitarian logics. We do indeed get a strong statistical relationship between welfare state generosity and overall well-being of the nations, as can be seen in figure 4.

The relationship to overall taxation level is similar. South Korea and Slovakia are the most significant outliers, but otherwise it is a fairly strong statistical relationship. We make no claim that correlations prove causal relationships, but it could be hypothesized that the tax, benefit and service state has a role in enhancing the well-being of nations, if properly functional.

As observed above the welfare state has indeed been an important mechanism for producing high qualities of life in the Nordic countries and on the North Western part of the European continent. That does not however mean that the welfare state is the sole means of raising the level of well-being nor is it inevitably the most important shaper of well-being. We return to that point further on in our discussion.

Figure 4. Association between well-being and welfare state generosity

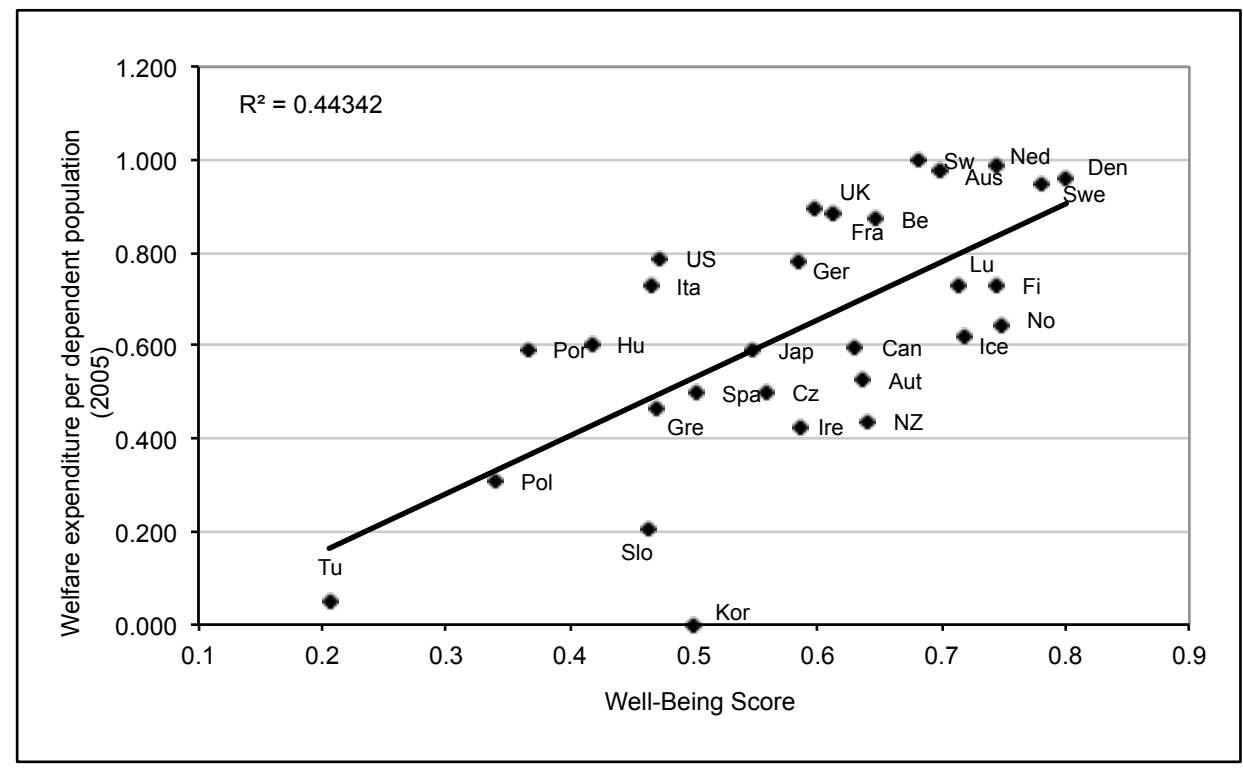

Relating our well-being measure to left-center-right political dimensions is difficult for our sample. This is for example because of the inclusion of formerly socialist states in Eastern Europe and the two Asian nations. Left politics there means a completely different thing from what it means in social democratic societies of Northern Europe. Hence we cannot apply a universal logic to that factor for all of our nations. Still we can of course recognize from former studies, such as Esping-Andersen's regime studies and Castles' studies of public policy patterns, that politics has been an important factor for welfare state development and for ameliorating the social stratification effects on com- 


\section{STJÓRNSÝSLA}

munities. That is likely to have reduced negative effects on the well-being of lower class groups in particular.

Still we would warn that the welfare state is not the sole generator of well-being of national publics, even though it has been important. Affluence level has a higher correlation to our (non-economic) well-being index than welfare state generosity. Affluence is of course an important part of nations' well-being, even though it also is not the sole generator of well-being, as economists used to think (OECD 2011a; Stiglitz et. al. 2009; Boarini et. al. 2006).

\subsection{Well-being, social capital and democracy}

When we correlate indicators of social capital or democracy to the WBI we find a stronger statistical relationship than for the welfare-tax state and affluence indicators. Social capital (measured as agreeing to: "Most people can be trusted") could possibly explain up to $62 \%$ of the variance of the well-being index, as against $44 \%$ for welfare state generosity.

Figure 5. Association between well-being and social capital/trust in other people

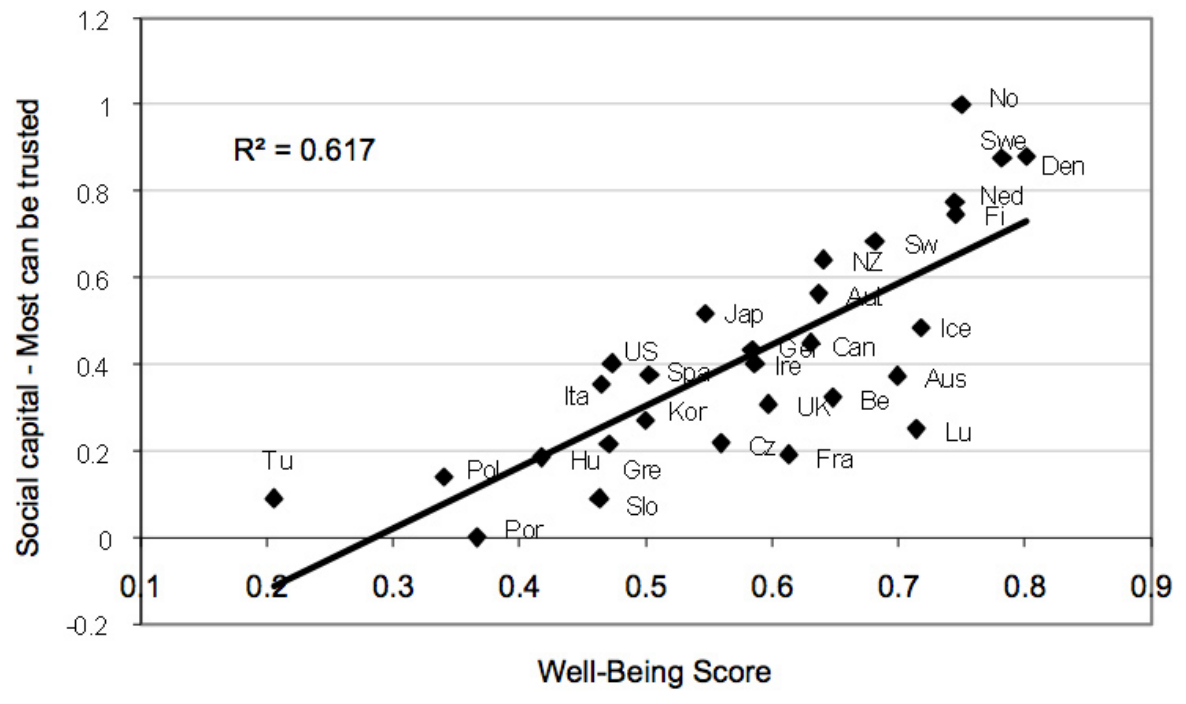

Norway is the main outlier, having a higher level of trust than expected at their well-being level, but modest deviants on the down side are Luxembourg and France. Otherwise this is a strong statistical association, possibly supporting hypotheses about the value of strong social fabrics for facilitating the workings of societies and strengthening foundations for economic growth, as well as for social cohesion and participation (Fukuyama 
1996; Helliwell and Putnam 2004; Larsen 2007). Social capital can be shown to be a facilitator for societal functioning and increased well-being of publics.

Social capital also facilitates the workings of democracy (Putnam 1993). And democracy may again facilitate increased well-being of publics, by making governments more responsive to the needs and preferences of the common public, rather than just being responsive to elites (Hirschman 1970).

As figure 6 shows there is indeed a very strong statistical relationship between the Economists' Democracy Index and our well-being measure (Pearson correlation .9). Such an association is indeed rare in social science. This could support claims that responsive, uncorrupt, professional and well functioning democracy and public administration is likely to facilitate well-being enhancements of the general population. This factor has perhaps too frequently escaped attention, but one could argue that voices from the grassroots are more likely to be heard in higher places in better functioning democracies than in other societies.

Figure 6. Association between well-being and strength of democracy (the Economists' Democracy Index for 2007)

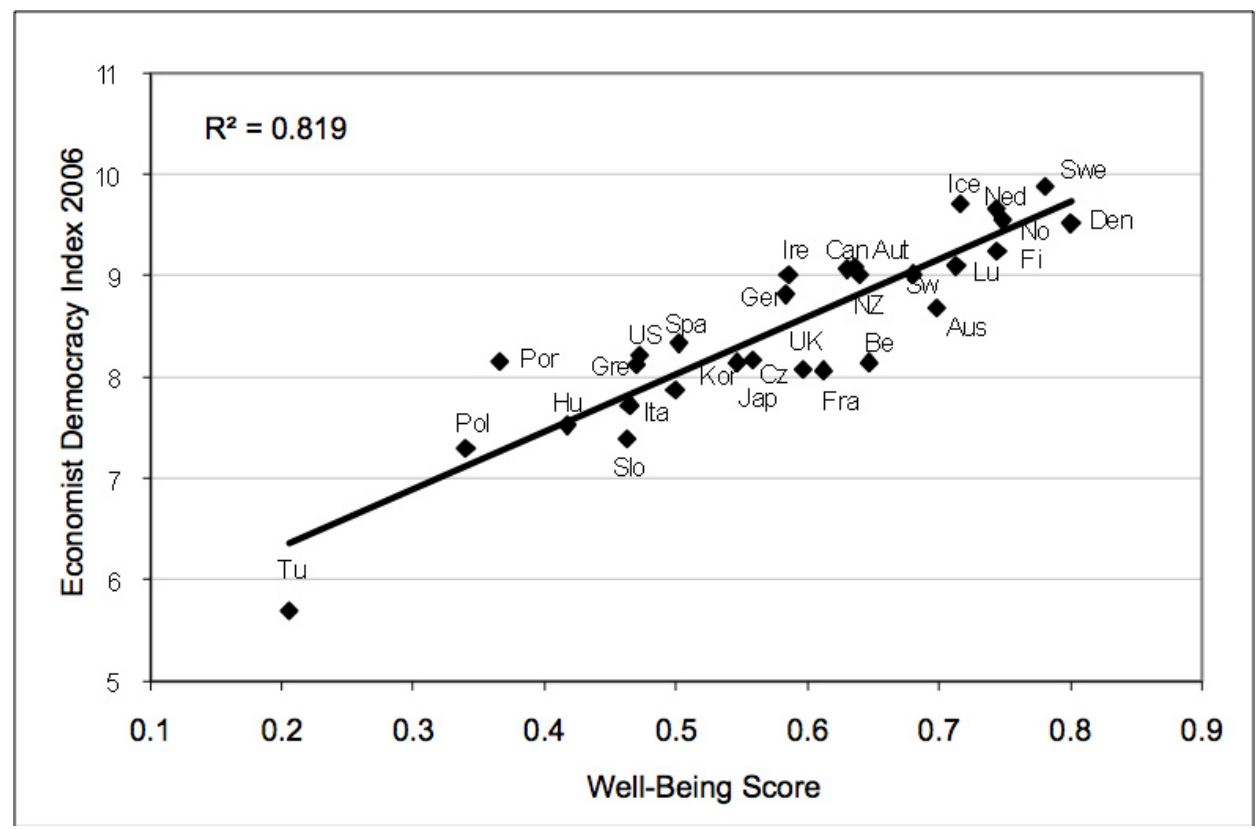

This may in some countries be even more important than left-right compositions of governments. An example of that might be Iceland, which for decades had a much weaker social democratic political influence than prevailed in the Scandinavian societies. Yet grassroot organizations, professionals and labour unions made frequent claims for welfare improvements in Iceland along the Scandinavian way. This was often success- 


\section{STJÓRNSÝSLA}

ful, even in periods of centre-right governments (Eydal and Ólafsson 2012; Ólafsson 1999).

Another factor of similar importance is the size of nations. If one looks at the countries that top the ranks both of strength of democracy and well-being (top right hand corner of figure 6) the predominance of relatively small states is outstanding. Witness Denmark, Sweden, Norway, Finland, Holland, Iceland, Luxembourg and Switzerland. With eight relatively small nations topping international rankings of both strength of democracy and well-being of publics there would seem to be a secure ground for arguing for the long-term importance of smallness for both societal characteristics. While smallness may not on its own secure success on these fronts it may facilitate such success (cf. Katzenstein 1985; Obinger et. al. 2010).

\subsection{Well-being and the position of the worst off}

The Rawlsian narrative of social justice stresses the principle of prioritizing the worst off in making distributive decisions in society (Rawls 1971). One can of course adhere to such a position on grounds of social justice. But the goal of maximizing the wellbeing of the majority of national publics may also lend support to giving priorities to the worse or worst off.

Raising the lower incomes in society indeed raises the median incomes of the general public of that society and reducing poverty similarly raises the scores of nations on many other well-being related factors. Hence lifting the bottom closer towards the median in level of living distributions, reducing poverty and poverty-related ills, improves the overall well-being situation. But this also applies to lifting of the lower middle higher up. This is a bottom-up distributional narrative which is well related to goals of equality of opportunities.

Correlating the equivalized real disposable earnings of the lowest decile of the population (data from OECD 2008) to our well-being index, indeed produces the very highest association that we find in a wide ranging scanning for associations, higher than the Democracy Index. As indicated in figure 7 the real position of the lowest income group could explain up to $87 \%$ of the variance in our well-being scores (Corr. .93). The statistical relationship is nearly perfect.

Thus the nations that provide the highest real disposable earnings to the lowest income groups also have the highest overall well-being rank. With such data one could promote an argument for the importance of lifting the bottom or the lower half when aiming to improve the average well-being of nations. The substantive argument, in addition to the statistical relationship, could evoke classical findings of poverty studies and studies of class divisions on poverty-related ills. William Beveridge (1942) for example talked about "the five giant evils" that his social protection system was supposed to ameliorate. Policies for social protection and social services have indeed most frequantly aimed at reducing such ills plaguing the worse off in society (Castles et. al. 2010). 
Well-Being in the Nordic Countries:

STJÓRNMÁL

An International Comparison

Stefán Ólafsson

Figure 7. Association between overall well-being and real earnings of the lowest income group (lowest decile of equivalized households' disposable earnings)

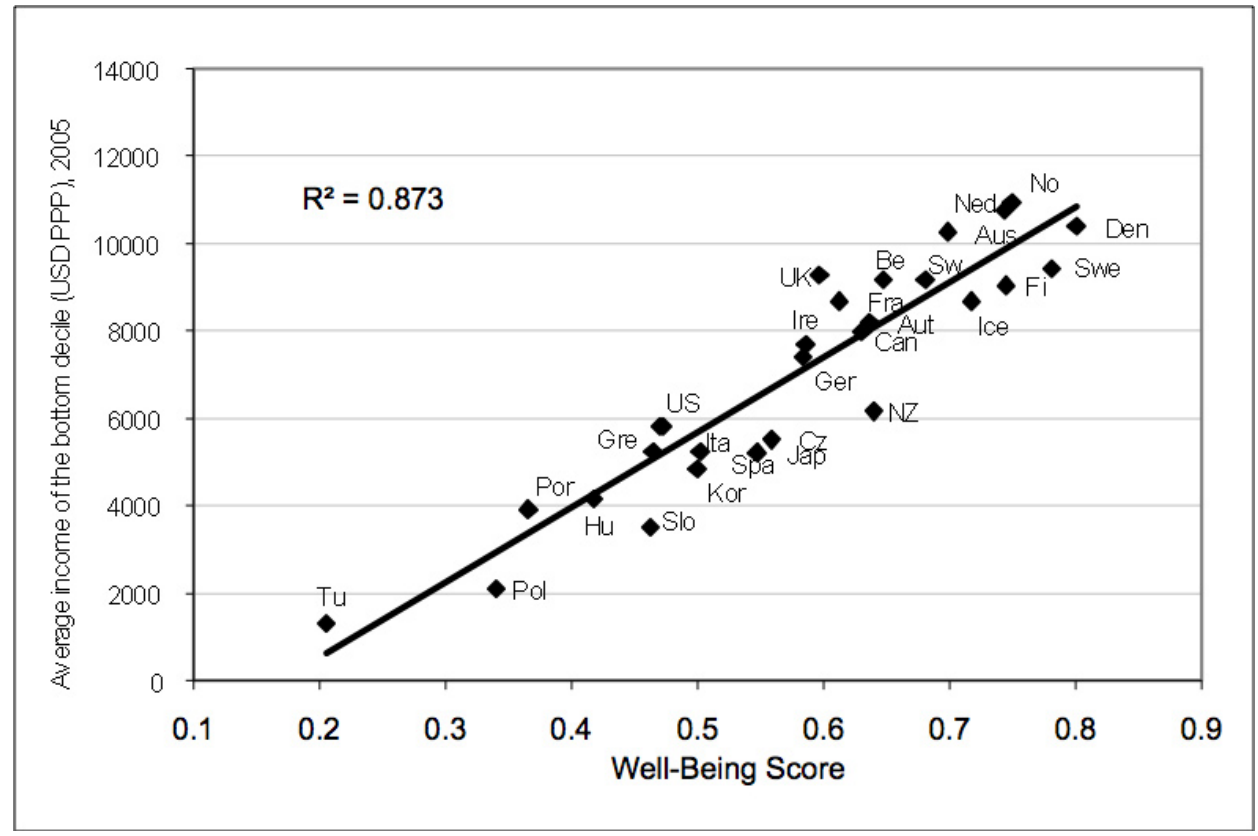

But there are also other ways of lifting the bottom and the middle. Increasing job opportunities (raising the employment level and reducing unemployment), improving educational opportunities, providing universal health care and redistributing incomes through the tax and benefits system are also important. Obtaining a very high affluence level is also of importance for improving the level of living of the worse off, in absolute terms. Thus the very affluent Luxembourg, Switzerland and Norway all hava a chance of scoring high compared to less affluent nations on various absolute poverty and material deprivation measures. Other nations, not so affluent, may need to rely more heavily on redistribution for that purpose. Those who both share a very high level of affluence and a modest redistributive regime, like Norway, will easily succeed in raising the bottom and the lower half significantly.

The USA on the other hand has a very high average affluence level in association with a very high level of inequality. When a very large part of the national income and wealth accrues to the top $10 \%$ or the top $1 \%$ less is available for the lower groups. In that case the worst off do not enjoy the affluence of the society to a comparable degree as in more equal yet similarly affluent societies. Such a societal environment, as in the USA, thus does not succeed as well in ameliorating various poverty-related ills. Hence the high affluence level is not reflected in a similarly high well-being level for the general public in that society. 
Thus is the win-win logic of foundations for well-being. Lifting the worse off not only relieves burdens of economic shortages but also facilitates a higher health standard for a larger part of the population, a higher educational standard and a more employable population. It thus improves human capital of the nation, facilitating further wins in the productivity and economic growth races. It also erodes risks of crime, conflict, exclusion and subjective suffering. It also seems to improve opportunities for the majority.

The lesson of this analysis of correlates of well-being is that the overriding goal of lifting the bottom and the lower middle is an important strategy for maximizing the wellbeing level of nations. There are many ways of approaching that goal: efficient economies, generous and effective welfare states, efficient educational systems, strong innovation environments, flexible and skilled labour forces, redistributive taxation systems and an open opportunity structure in a participative and incusive democratic environment.

\section{Conclusion}

At the beginning of this study we asked if the Nordic nations had maintained their high level of well-being for the majority of their citizens, despite wide-ranging changes in their external and internal societal environments during the last two decades. That is an important question for assessing the relevance of the Nordic model or the Nordic way of organizing societies, in the new environment of globalization and internal challenges of industrial change, aging and modernization. To answer that question we have to rely on the comparative method. For that purpose we constructed a multi-dimensional data bank of well-being outcome measures, sixty nine measures in all for twenty nine modern nations. The data primarily covers the period leading up to the financial crisis of 2008 and onwards, i.e. the 2005 to 2008 period.

Thus we seek to answer our lead question by comparing the well-being outcomes for the Nordic nations with that of other modern nations. The comparative dimensions that our measures cover are economic strength (affluence and competitiveness), health conditions, employment levels, educational levels, income equality, poverty reduction, family conditions, social cohesion and participation, and subjective well-being.

The findings indicate that the Nordic nations, including Iceland, have the highest level of well-being amongst modern nations, along with Netherlands, Switzerland and Luxembourg. In that sense the Nordic model has stood the test of time through the changes of neoliberal globalization and internal changes. While inequality increased for many nations leading up to the financial crisis of 2008 and onwards, including in the Nordic nations and most decisively for Iceland, the relatively good well-being position of the Nordics was maintained (Kvist et. al. 2012). Iceland however went much deeper into the crisis with consequent well-being setbacks, along with other crisis countries, such as Ireland. It will be of great interest to repeat a survey of well-being outcomes when the financial crisis is fully behind us.

Our analysis of well-being outcomes produces a clustering of nations which is very comparable to the families of nations clusters and the welfare regimes clusters, which are primarily based on welfare input or public policy patterns. The similarity of cluster- 
ing by welfare antecedents and well-being outcomes indicates that societal structures and policy patterns shape well-being outcomes in a similar way as they shape welfare state and other societal characteristics (Castles and Obinger 2008).

The Nordic cluster of nations has decisive characteristics of foundations for wellbeing of the majority of their citizens. This is their emphasis on equality of income distribution, poverty reduction, improving family conditions and facilitating social cohesion and participation, while also facilitating economic strength and a high affluence level. These features are also associated with high levels of health for their populations and a high level of subjective satisfaction with life.

Scanning correlates of overall well-being outcomes supports the contention that the shapers of modern welfare states are also important for well-being outcomes of the publics. Our analysis however also draws attention to the decisive importance of social capital, trust and democracy for facilitating well-being.

The strongest association we find to well-being outcomes of modern nations is the real disposable earnings level of the lowest income group in these societies (the lowest income decile). That supports a narrative emphasizing the importance of lifting the bottom, or the lower half, of the households up the level of living ladder. Such a strategy of equality succeeds best in improving the overall well-being level of modern nations.

There are however many ways of lifting the absolute living standards of the worse off. The Nordic welfare model is one of them, but the welfare system has to accomodate to other important factors, such as an efficient economy, educational system and an inclusive, innovative and democratic social environment.

\section{Appendix}

\section{A.1 Design of the Well-Being Index}

The methodology for constructing the WB Index is similar to that of UN's Human Development Index, except our index has many more dimensions and variables. The HDI core measure is based on 3 dimensions and 4 variables. When aiming for a broader design of such an index, with much greater number of variables to base it on, one has to limit the index to fewer nations due to lack of comparable data. The HDI covers a very large number of nations with few and rather limited measures of quality of life. We have more broadly based measures but for fewer nations. Thus we deal only with selected modern nations. At this stage 29 nations are fully covered by the WBI index and sub-indices. The selection of nations is data driven, determined by data availability. The majority of the measures are aggregate measures of objective aspects but a significant number of variables are derived from survey-based micro-data on subjective factors. From these measures, normalized onto a unitary scale from 0 to 1 , we derive sub-index scores, the average of which forms the total Well-Being Index. There is no weighting of variables or dimensions.

Most of the variables in our index relate to the period of 2005-2008, but in exceptional cases they cover averages for longer periods. Thus data on affluence levels (GDP per capita in US\$ with purchasing power parities) are averages for 2000-2007 and in the 


\section{STJÓRNSÝSLA}

69 variables version we have also exceptionally included one measure of GDP pc for 1990-1999, recognizing that economic affluence is best measured on longer-term averages. In this case effects of the overheated economies, even extreme bubble economies, in the advent of the international economic crisis starting in 2007-8 are restricted in the overall measures. In other cases, such as in data from Gallup World Poll, some variables refer to 2008 or 2009, thus reflecting some effects of the crisis on subjective attitudes and assessments.

Given that many nations will be carrying burdens from the financial crisis for some time to come this may give a more realistic picture of the subjective outcome for the next few years than if the subjective data were only based on data from the pre-crisis period. Ireland and Iceland, two countries that experienced excessive bubble economies and that were particularly badly hit by the financial crisis, had for example lowered their level of life satisfaction already by 2006. Measures of life satisfaction in these countries from 2008-9 are in fact higher or on similar level as in 2006, but that is though significantly lower than these nations were previously showing on that measure, such as in 2000 and in 1990. If we had used data on life satisfaction from the year 2000 we would thus be giving a distorted picture of life satisfaction amongst these nations at present and most likely in the immediate future. Such considerations may apply to other subjective variables and other nations too.

When data was missing for individual cases we used data from another time point close to the original one. When that was not possible we used regression technique to estimate the missing value, by relying on an estimate from another variable closely correlated to the variable with the missing value. Such estimates were however minimal in number.

One of the biggest omissions in our index is housing quality. This was omitted because a comparable measure across all our nations was not available, except for the EU member states. When correlating our well-being index to satisfaction with accomodation and a number of other housing indicators for EU states we obtain very high correlations, suggesting that inclusion of comparable housing variables would not significantly change the overall well-being index. See futher information on the data and well-being index at www.ts.hi.is/gagnagrunnur.

\section{A.2 List and sources of variables on which the WB-Index is based}

\section{Economic strength}

GDP per head, US \$, constant prices and PPPs, ref. year 2000 - Average 2000-2007 (OECD)

The Global Competitiveness Index 2009-2010 score (World Economic Forum)

Income levels for people at different points in the distribution, mid 2000s - Median income (USD PPP)(OECD)

Real GDP Growth, annual growth in \% - Average 2000-2007 (OECD)

GDP per head, US \$, constant prices, constant PPPs, reference year 2000 - Average 1990-1999 (OECD)

Health conditions

Life expectancy at birth 2007 - Total years. (OECD)

Potential years of life lost [Premature mortality], 2006 - Males (Per 100.000) (OECD) 
Suicide, mortality rates, 2006 - Total (Per 100.000) (OECD and WHO)

Infant mortality rates 2007 (Per 1.000) (OECD and WHO)

Percentage of adult population with Body Mass Index over 30 (obese population), around 2007 - Total (OECD)

Average number of decayed, missing or filled teeth, 12y old, 2006 (OECD)

Experience depression yesterday, 2008 or 2009 (\% Yes) (Gallup WP)

AIDS incidence rates, 2006 (New cases per million population) (OECD)

Percentage of adult population smoking daily, 2007 - Total ( $\%$ of $15 \mathrm{y}$ and over) (OECD)

Alcohol consumption in litres per capita, population aged 15+, 2007 (OECD)

Out of pocket and private health insurance as a share of total health expenditure, 2007 - Total (OECD)

\section{Employment level}

Employment/population ratio (Persons aged 15-64 years (percentages)) - Average of 2005-2008 (OECD)

Unemployment rate (Men aged 15-64 \%) - Average of 2004-2008 (OECD)

Unemployment rate (Women aged 15-64, \%) - Average of 2004-2008 (OECD)

Share of population living in jobless households: Level around 2005 (OECD)

Average annual hours actually worked per person in employment - Total employment - Average for 2005-2008 (OECD)

Employment/population ratio (Women aged 15-64 years, \%) - Average of 2004-2008 (OECD)

Employment/population ratio, age 55 to 64, Both sexes - Average of 2005-2008 (OECD)

Employment/population ratio, Persons aged 25-64 (\%), Both sexes, 2007 - Less than upper secondary education (OECD)

ALMP - Public expenditure as a percentage of GDP - Total, 2005-2006 (OECD)

\section{Educational level}

Population with at least upper secondary education, 25-34 year-olds, 2007 (OECD)

Population that has attained at least tertiary education, 25-34 year-olds, 2007 (OECD)

Mean score in science, 2006 - PISA results (OECD)

Mean score in mathematics, 2006 (OECD)

Population with at least upper secondary education, 55-64 year-olds, 2007 (OECD)

Population with tertiary education, 25-64 year-olds, 2007 (OECD)

\section{Income equality (sharing of GDP)}

Gini coefficients of income inequality in OECD countries, mid 2000s (OECD and LIS)

Levels of income inequality - Inter-decile ratio P90/P10: Level mid 2000s (OECD and LIS)

Levels of income inequality based on different summary measures in mid-2000s - Inter-decile ratio P50/P10: Level (OECD)

\section{Poverty reduction}

Relative poverty rates for different income thresholds, mid-2000s - proportion below 50\% of median equivalized income (OECD)

Poverty rates among children, Mid-2000s (OECD)

Poverty among people of retirement age, Mid-2000s (OECD)

Prevalence of different forms of material deprivation ( $\%$ of total population) - Inability to make ends meet, mid 2000s (OECD)

Relative poverty rates for different income thresholds, mid-2000s - 40\% of median (OECD)

Poverty in households with a head of working age: All, 2005 (OECD)

Poverty in households with children; Single, Working, 2005 (OECD) 


\section{STJÓRNSÝSLA}

\section{Family conditions}

Young males not in employment, education or training in the OECD (\% age 15-19), 2006 (OECD)

Public and mandatory private expenditures on welfare - Family, Cash benefits, Family allowances (\% of GDP) - 2005 (OECD)

Public and mandatory private expenditures on family benefits in kind (Day care/Home-help services), \% of GDP 2005 (OECD)

Enrolment rates of children aged three to five years of age in pre-school educational programmes, 2006 (OECD)

Gender equality score 2009 (Global Gender Gap Index)(World Economic Forum 2009)

Mean age of mothers at first childbirth, 2005 (OECD)

Net income solely on social assistance for sole parents with two children/median equivalent household income, 2005 (OECD)

Public social expenditure by broad social policy area, in percentage of NNI, 2005 - All social services except health (OECD)

Average of proportion of the 20-24 year-old cohort not in education and not employed between 1997 and 2007 (OECD)

\section{Social Cohesion \& Participation}

Voter turnout in parliamentary elections (\% of voting age population-latest available year)(www.idea.int/vt/)

Corruption Index (Gallup WP 2008-2009)

Employment participation of people with disabilities, \% around 2005 (OECD)

National Institutions Index (Gallup WP 2008-2009)

Community Basics Index (Gallup WP 2008-2009)

Law \& Order Index (Gallup WP 2008-2009)

Food \& Shelter Index (Gallup WP 2008-2009)

\section{Subjective Well-Being}

Thriving Index (Gallup WP 2008-2009)

Struggling Index (Gallup WP 2008-2009)

Suffering Index (Gallup WP 2008-2009)

Personal Health Index (Gallup WP 2008-2009)

Experience stress yesterday (\% Yes) (Gallup WP 2008-2009)

Life satisfaction today (Gallup WP 2008-2009)

Average points of life satisfaction on an 11-step ladder from 0-10, 2006 (OECD)

Personal Economy Index (Gallup WP 2008-2009)

Citizen Engagement Index (Gallup WP 2008-2009)

Youth Development Index (Gallup WP 2008-2009)

Diversity Index (Gallup WP 2008-2009)

Violence Index (Gallup WP 2008-2009)

\section{References}

Allardt, E. and Uusitalo, H. (1972). Dimensions of Welfare in a Comparative Study of the Scandinavian Societies. Scandinavian Political Studies, volume 7, issue A7, pages 9-27.

Allardt, E. (1975). Att ha, att älska, at vara. Lund: Seelig.

Árnason, J. P. and Wittrock, B. (2012). Nordic Paths to Modernity. Oxford: Berghahn Books.

Art, W. A. and Gelissen, J. (2002). "Three worlds of welfare capitalism or more? A state-of-the-art report", in Journal of European Social Policy, vol. 12 (2): 137-158.

Atkinson, A. B., Cantillon, B., Marlier, E. and Nolan, B. (2002). Social Indicators: The EU and Social Inchsion. Oxford: OUP. 


\section{STJÓRNMÁL $\&$ STJÓRNSÝSLA}

Atkinson, A. B. and Piketty, T. (2010). Top Incomes: A Global Perspective. Oxford: OUP.

Atkinson, A. B. and Marlier, E. (2010). Income and Living Conditions in Europe. Luxembourg: Eurostat.

Bertelsmann Stiftung (2011). "Social Justice in the OECD - How Do the Member States Compare? Sustainable Governance Indicators 2011”. Report awailable at www.bertelsmann-stiftung.de.

Beveridge, W. (1942). Social Insurance and Allied Services (the Beveridge Report). London : HMSO.

Boarini, R., A. Johansson and M. M. d'Ercole (2006). "Alternative Measures of Well-Being", OECD Social, Employment and Migration Working Papers, No. 33, OECD Publishing.

Bradshaw, J., Hoelscher, P. and Richardson, D (2006). "Comparing Child Well-Being in OECD Countries: Concepts ans Methods". UNICEF: Innocento Research Centre, IWP-2006-03.

Castles, F. G. (1978). The Social Democrtatic Image of Society. London: Routledge \& Kegan Paul.

Castles, F.G. (1993). Families of Nations: Patterns of Public Policy in Western Democracies, Dartmouth: Aldershot.

Castles, F. G. 1998, Comparative Public Policy: Patterns of Post-War Transformation, Edward Elgar Publishing, Cheltenham, UK.

Castles, F. G. \& Obinger, H. (2008). 'Worlds, Families, Regimes: Country Clusters in European and OECD Area Public Policy', West European Politics, vol. 31, no. 1-2, pp. 321-344.

Castles, F. G., Leibfried, S., Lewis,J., Obinger, H. and Pierson, C. (2010). Oxford Handbook of the Welfare State. Oxford: OUP.

Corak, M. (2013). Income Inequality, Equality of Opportunity, and Intergenerational Mobility, in Journal of Economic Perspectives, volume 27, no. 3, pp. 79-102.

Erikson, R., Hansen, E.J., Ringen, S., \& Uusitalo, H. (eds.) (1987). The Scandinavian Model: Welfare states and welfare research. New York: M.E. Sharpe.

Economist (2007). Democracy index 2007. A report from the Economist Intelligence Unit. Available at www.economist.com.

Esping-Andersen, G. (1985). Politics Against Markets. Princeton: PUP.

Esping-Andersen, G. \& Korpi, W. (1987). From Poor Relief to Institutional Welfare States: The development of Scandinavian Social Policy. In: R. Erikson et al. (eds.), The Scandinavian Model: Welfare states and welfare research, New York: M.E. Sharpe.

Esping-Andersen, G. (1990). The Three Worlds of Welfare Capitalism, Princeton, N.J.: Princeton University Press.

Esping-Andersen, G. (1999). The Social Foundations of Postindustrial Economies, Oxford: Oxford University Press.

Eurofound (2009). Second European Quality of Life Survey. Available at www.eurofound.ie.

Eurofound (2010). Trends in quality of life in the EU, 2003-2009. Available at www.eurofound.ie.

Eydal, Guðný B. and Ólafsson, Stefán (2012). Próun velferðarinnar 1988-2008. Reykjavík: Social Sciences Research Institute, University of Iceland.

Ferrera, M. (2010). “The Southern European Countries”, in Castles et. al. (eds), The Oxford Handbook of the Welfare State. Oxford: OUP.

Fukuyama, F. (1996). Trust: The Social Virtues and The Creation of Prosperity. New York: Free Press.

Gallup-Healthways (2009). Well-Being Index: Methodology Report for Indexes. Available on www. gallup.org.

Gallup International (2010). Global Wellbeing - The Behavioral Economics of GDP Growth. Available on www.gallup.org.

Helliwell, John F. and Putnam, R. D. (2004). "The social context of well-being". Royal Society: Phil. Trans. R. Soc. Lond. B 29 September 2004, vol. 359 no. 1435-1446.

Helliwell, Layard and Sachs (2012). World Happiness Report. Columbia: The Earth Institute (http:// www.earth.columbia.edu/sitefiles/file/Sachs\%20Writing/2012/-World\%20Happiness\%20Report. pdf).

Hirschman, A. O. (1970). Exit, Voice, and Loyalty: Responses to Decline in Firms, Organizations, and States. Boston: Harvard University Press. 


\section{STJÓRNSÝSLA}

Johansson, S. (1973). Review Symposium On the 1968 Level of Living Survey in Sweden. Acta Sociologica, July 1973 16: 211-224.

Johansson, S. (2002). Conceptualizing and Measuring Quality of Life for National Policy. In Social Indicators Research Series, Volume 11, pp. 13-32.

Katzenstein, Peter J. (1985). Small States in World Markets: Industrial Policy in Europe. Ithaca, Cornell University Press.

Kautto, M., Fritzell, J., Hvinden, B., Kvist, J., and Uusitalo, H. (2001). Nordic Welfare States in the European Context, London: Routledge.

Kersbergen, Keez van and Manow, P. (2009). Religion, Class Coalitions, and Welfare States. Cambridge: CUP.

Korpi, W. (1983). Democratic Class Struggle. London: Routledge \& K. Paul.

Kvist, Jon, Johan Fritzel, Bjørn Hvinden \& Olli Kangas (2012) (eds.). Changing Social Equality: The Nordic welfare model in the 21st century. Bristol: The Policy Press.

Larsen, Christian A. (2007). "How Welfare Regimes Generate and Erode Social Capital: The Impact of Underclass Phenomena", in Comparative Politics, Vol. 40, No. 1 (Oct., 2007), pp. 83-101.

Lipset, S. M. (1963). The First New Nation. New York: Basic Books.

Marlier, E., Atkinson, A. B., Cantillon, B. and Nolan, B (2007). The EU and Social Inclusion: Facing the Challenges. Bristol: Policy Press.

Nolan, B, and Whelan, C.T. (2011) Poverty and Deprivation in Europe . Oxford : Oxford University Press.

Obinger, H. and Wagschal, U. (2001). "Families of Nations and Public Policy", in West European Politics, 24:1, 99-114.

Obinger, H., Peter Starke, Julia Moser, Claudia Bogedan, Edith Gindulis, and Stephan Leibfried (2010). Transformations of the Welfare State - Small States, Big Lessons. Oxford: OUP.

OECD (2008). Growing Unequal? Paris: OECD.

OECD (2009a). Society at a Glance. Paris: OECD.

OECD (2009b). Doing better for children. Paris: OECD.

OECD (2011a). How's Life - Measuring Well-being. Paris: OECD.

OECD (2011b). Compendium of OECD Well-Being Indicators. Paris: OECD

OECD (2011c). Divided We Stand: Why Inequality Keeps Rising. Paris: OECD.

OECD (2012). Education at a Glance. Paris: OECD.

Osberg, L. and Sharpe, A. (2009). New Estimates of the Index of Economic Well-being for Selected OECD Countries,1980-2007. Center for Study of Living Standards (CSLS), Research Report 200911. Available at http://www.csls.ca/reports/csls2009-11.pdf.

Osberg, L. and Sharpe, A. (2011). Moving from a GDP based to a Well-being Based Metric of Economic Performance and Social Progress: Results from the Index of Economic Well-being for OECD Countries, 1980-2009. Center for Study of Living Standards (CSLS), Research Report 2009-11. Available at http://www.csls.ca/reports/csls2009-11.pdf.

Ólafsson, Stefán (1990). Lifskejör og lifshattir á Nordurlöndum - Samanburdur á pjóðfélagi Íslendinga, Dana, Finna, Nordmanna og Svía. Reykjavík: Iðunn.

Ólafsson, Stefán (1999). Íslenska leidin: Almannatryggingar og velferơ i fjölpjódlegum samanburdi. Reykjavík: University Press and Social Security Administration.

Ólafsson, Stefán (2010). "Árangur frjálshyggjunnar - Samanburður lífskjara í frjálshyggjuríkjum og velferðarríkjum”, in Eiliffarvélin - Uppgöör við nýfrjálshyggjuna, Kolbeinn H. Stefánsson (ed.). Reykjavík: University Press.

Ólafsson, Stefán (2012). "Inngangur - Lífskjörin 1988 og 2008”, in Dróun velferðarinnar 1988-2008, Guðný B. Eydal and Stefán Ólafsson (eds). Reykjavík: Social Sciences Research Institute, University of Iceland.

Putnam, R. D: (1993). Making Democracy Work. Princeton: Princeton Universitiy Press.

Rawls, J. (1971). A Theory of Justice. Boston: The Belknap Press of Harvard University Press. 
Stiglitz, J. Sen, A. and Fitoussi, J-P. (2009). Report of the Commission on the Measurement of Economic Performance and Social Progress. Available at http://www.stiglitz-sen-fitoussi.fr/en/index.htm.

Smeeding, T. (2012). "New Comparative Measures of Income, Material Deprivation, and Well-Being", in Douglas J. Besharov and Kenneth A. Couc (eds). Counting the Poor: New Thinking About European Poverty Measures and Lessons for the United States. Oxford: OUP.

UNICEF Office of Research (2013). 'Child Well-being in Rich Countries: A comparative overview', Innocenti Report Card 11, UNICEF Office of Research, Florence.

Whelan, C. T. and Maitre, B. (2009). "Welfare Regime and Social Class Variation in Poverty and Economic Vulnerability in Europe: An Analysis of EU-SILC”. ESRI Working Paper no. 303.

Whelan, C. T. \& Maitre, B. (2012). "Understanding Material Deprivation in Europe: A Multilevel Analysis," Working Papers 201205, Geary Institute, University College Dublin.

Wilkinson, R. and Pickett, K. (2010). The Spirit Level: Why Equality is Better for Everyone. London: Bloomsbury Publishing.

World Economic Forum (2009). Global Gender Gap Report 2009. Available at www.weforum.com. 
STJÓRNSÝSLA 